\title{
Identification of prolylcarboxypeptidase as the cell matrix-associated prekallikrein activator
}

\author{
Claudia R. Moreira ${ }^{\mathrm{a}}$, Alvin H. Schmaier ${ }^{\mathrm{b}, \mathrm{c}, *}$, Fakhri Mahdi ${ }^{\mathrm{b}}$, Guacyara da Motta $^{\mathrm{a}}$, \\ Helena B. Nader ${ }^{\mathrm{a}}$, Zia Shariat-Madar ${ }^{\mathrm{b}}$ \\ ${ }^{a}$ Departmento de Bioquimica, Universidade Federal de Sao Paulo, Sao Paulo, Brazil \\ ${ }^{\mathrm{b}}$ Division of Hematology and Oncology, Department of Internal Medicine, University of Michigan, Ann Arbor, MI, USA \\ ${ }^{c}$ Department of Pathology, University of Michigan, Ann Arbor, MI, USA
}

Received 2 May 2002; revised 7 June 2002; accepted 7 June 2002

First published online 25 June 2002

Edited by Beat Imhof

\begin{abstract}
Investigations determined that the cell matrix-associated prekallikrein (PK) activator is prolylcarboxypeptidase. PK activation on human umbilical vein endothelial cell (HUVEC) matrix is inhibited by antipain $\left(\mathrm{IC}_{\mathbf{5 0}}=\mathbf{5 0} \mu \mathrm{M}\right)$ but not antifactor XIIa antibody, $3 \mathrm{mM}$ benzamidine, $5 \mathrm{mM}$ iodoacetic acid or iodoacetamide, or $3 \mathrm{mM} N$-ethylmaleimide. Corn trypsin inhibitor $\left(\mathrm{IC}_{50}=100 \mathrm{nM}\right)$ or Fmoc-aminoacylpyrrolidine-2nitrile $\left(\mathrm{IC}_{50}=100 \mu \mathrm{M}\right)$ blocks matrix-associated $\mathrm{PK}$ activation. Angiotensin II $\left(\mathrm{IC}_{50}=100 \mu \mathrm{M}\right)$ or bradykinin $\left(\mathrm{IC}_{50}=\mathbf{3 M}\right)$, but not angiotensin 1-7 or bradykinin 1-5, inhibits matrix-associated PK activation. ECV304 cell matrix PK activator also is blocked by $100 \mu \mathrm{M}$ angiotensin II, $1 \mu \mathrm{M}$ corn trypsin inhibitor, and $50 \mu \mathrm{M}$ antipain, but not angiotensin 1-7. $1 \mathrm{mM}$ angiotensin II or $300 \mu \mathrm{M}$ Fmoc-aminoacylpyrrolidine-2-nitrile indirectly blocks plasminogen activation by inhibiting kallikrein formation for single chain urokinase activation. On immunoblot, prolylcarboxypeptidase antigen is associated with HUVEC matrix. These studies indicate that prolylcarboxypeptidase is the matrix PK activator. (C) 2002 Federation of European Biochemical Societies. Published by Elsevier Science B.V. All rights reserved.
\end{abstract}

Key words: Prolylcarboxypeptidase;

Lysosomal carboxypeptidase; Angiotensinase C;

Prekallikrein; Single chain urokinase; Angiotensin II; Bradykinin

\section{Introduction}

Previous investigations have shown that when high molecular weight kininogen $(\mathrm{HK})$ and prekallikrein $(\mathrm{PK})$ assemble on matrix of human umbilical vein endothelial cells (HUVEC) or ECV304 cells, PK becomes activated to kallikrein [1]. This finding suggests that the plasma kallikrein/kinin system participates in matrix-associated activities such as wound healing,

*Corresponding author. University of Michigan, 5301 MSRB III, 1150 West Medical Center Drive, Ann Arbor, MI 48109-0640, USA. Fax: (1)-734-647 5669

E-mail address: aschmaie@umich.edu (A.H. Schmaier).

Abbreviations: HK, high molecular weight kininogen; PK, prekallikrein; HUVEC, human umbilical vein endothelial cells; CTI, corn trypsin inhibitor; PRCP, prolylcarboxypeptidase; ATII, angiotensin II; BK, bradykinin; Ang 1-7, angiotensin 1-7; BK 1-5, bradykinin 15; ZPP-OH, Z-Pro-Pro-OH; FMOC, Fmoc-aminoacylpyrrolidine-2nitrile; ScuPA, single chain urokinase plasminogen activator tissue remodeling, and angiogenesis. PK activation on cell matrix was inhibited by antipain and corn trypsin inhibitor (CTI) [1]. The PK activating enzyme on cell matrix is present when the endothelial cells were grown in factor XII deficient serum, indicating that PK activation is independent of factor XIIa [1]. Kallikrein formation on extracellular matrix was essential for single chain urokinase activation and subsequent plasmin formation $[1,2]$. The activation and inhibitory pattern for PK on endothelial cell matrix is similar to that which has been described for PK on confluent monolayers of cultured endothelial cells $[2,3]$. Recent investigations indicate that the enzyme prolylcarboxypeptidase (PRCP, lysosomal carboxypeptidase, or angiotensinase $\mathrm{C}$ ) is the endothelial cell PK activator that functions independent of factor XIIa [4]. The present investigations show that PRCP is the PK activator associated with endothelial cell matrices.

\section{Materials and methods}

\subsection{Materials}

Angiotensin II (ATII) and antipain hydrochloride were purchased from Calbiochem (San Diego, CA, USA). Single chain HK, human PK, human Glu-plasminogen, CTI, and a neutralizing polyclonal goat anti-human antibody to human factor XII were purchased from Enzyme Research Laboratories (South Bend, IN, USA) [4]. Biotinylated HK was prepared as previously reported $[1,2]$. Bradykinin (BK), bradykinin 1-5 (BK 1-5) (RPPGF), aprotinin, and angiotensin 1-7 (Ang 1-7) were purchased from Sigma (St. Louis, MO, USA). Prestained low molecular weight standards, polyacrylamide and nitrocellulose membrane was obtained from Bio-Rad (Richmond, CA, USA). HUVEC, trypsin-EDTA, trypsin neutralizing buffer, bovine brain extract, fetal bovine serum (FBS) and endothelial growth medium (EGM) were purchased from Clonetics (San Diego, CA, USA). The chemiluminescence ECL detection system was obtained from Amersham (Arlington Heights, IL, USA). Triton X-100 was purchased from Boehringer-Mannheim (Indianapolis, IN, USA). Single chain urokinase plasminogen activator (ScuPA) was obtained from American Diagnostica (Greenwich, CT, USA). Peptide Z-Pro-Pro-OH (ZPP-OH) was purchased from Bachem (King of Prussia, PA, USA). H-D-ProPhe-Arg-paranitroanilide (S2302) and Val-Leu-Lys-paranitroanilide (S2251) were purchased from Diapharma (Franklin, OH, USA). Fmoc-aminoacylpyrrolidine-2-nitrile (FMOC), a potent prolyl oligopeptidase inhibitor, was generously provided by Dr. Sherwin Wilks, Mount Sinai Medical School, New York, NY, USA [5]. Rabbit antiserum against PRCP was generously provided by Dr. Randal Skidgel, University of Illinois, Chicago, IL, USA.

\subsection{Endothelial cell culture}

HUVEC were maintained in EGM supplemented with 2\% FBS and bovine brain extract in an incubator with $5 \% \mathrm{CO}_{2}$ at $37^{\circ} \mathrm{C}$. HUVEC cells from the 1st to 5 th passages were cultured on fibronectin $(2 \mathrm{mg} /$ $\mathrm{ml})$ coated 96-well plates and used within $24 \mathrm{~h}$. ECV304 cells were 
grown to confluence on $60 \mathrm{~mm}$ dishes in Ham F-12 Nutrient Mixture medium (Life Technologies, Gaithersburg, MD, USA) supplemented with $10 \%$ heat-inactivated fetal calf serum (Cultilab, Campinas, SP, Brazil) containing $10 \mathrm{U}$ penicillin and $10 \mu \mathrm{g}$ streptomycin/ml (Life Technologies). In preparation for binding experiments, ECV304 cells were removed from their culture dishes after incubation for $40 \mathrm{~min}$ with $3.73 \mathrm{mg} / \mathrm{ml}$ pancreatin (Sigma) and grown in 96-well microtiter plates at $37^{\circ} \mathrm{C}$ under $2.5 \% \mathrm{CO}_{2}$. These cells were used within $24 \mathrm{~h}$ of becoming confluent.

\subsection{Preparation of the extracellular matrix}

Confluent monolayers of HUVEC or ECV304 cells in 96-well microtiter plate wells were washed with $0.15 \mathrm{M} \mathrm{NaCl}, 0.01 \mathrm{M}$ sodium phosphate, pH 7.4 (PBS) and then removed after 15 min treatment with $0.5 \%$ Triton X-100 in PBS [1]. The plate was then incubated with $0.025 \mathrm{M} \mathrm{NH}_{4} \mathrm{OH}$ for $10 \mathrm{~min}$ [1]. The matrix was washed five times with $0.02 \mathrm{M}$ Tris $-\mathrm{HCl}, 0.15 \mathrm{M} \mathrm{NaCl}, \mathrm{pH} 7.4$ containing $0.05 \%$ Tween 20 followed by washing five times with HEPES-Tyrode buffer $\left(0.135 \mathrm{M} \mathrm{NaCl}, 14.7 \mathrm{M}\right.$ HEPES, $2.7 \mathrm{M} \mathrm{KCl}, 0.36 \mathrm{mM} \mathrm{NaH}_{2} \mathrm{PO}_{4}$, $11.9 \mathrm{mM} \mathrm{NaHCO}, 3.5 \mathrm{mg} / \mathrm{ml}$ dextrose, $2 \mathrm{mM} \mathrm{Ca}^{2+}, 1 \mathrm{mM} \mathrm{Mg}^{2+}$, $3.5 \mathrm{mg} / \mathrm{ml}$ bovine serum albumin, $\mathrm{pH}$ 7.35). All the incubations were performed under the same conditions in an incubator with $5 \% \mathrm{CO}_{2}$ at $37^{\circ} \mathrm{C}$. In all cases after this treatment, no cells were detected by light microscopy

\subsection{PK activation on matrix}

HUVEC matrix was incubated with $100 \mu \mathrm{l}$ of $20 \mathrm{nM}$ HK in HEPES-Tyrode buffer containing $50 \mu \mathrm{M} \mathrm{Zn}{ }^{2+}$ (binding buffer) for $1 \mathrm{~h}$ at $37^{\circ} \mathrm{C}$. The HK was removed and then the matrix was incubated with $100 \mu \mathrm{l}$ of $20 \mathrm{nM}$ PK in binding buffer for $1 \mathrm{~h}$ at $37^{\circ} \mathrm{C}$. The matrix was washed to remove any unbound PK. Formed kallikrein activity was determined by the hydrolysis of $100 \mu \mathrm{l} \mathrm{S} 2302(0.8 \mathrm{mM})$ for $1 \mathrm{~h}$ at $37^{\circ} \mathrm{C}$. The hydrolysis of the substrate was measured at $405 \mathrm{~nm}$ using a Microplate auto reader EL 311 (Bio-Tek Instrument, Winooski, VT, USA). Alternatively, PK activation on ECV304 matrix was measured by hydrolysis of $0.4 \mathrm{mM} \mathrm{S} 2302$ for $2 \mathrm{~h}$ at $37^{\circ} \mathrm{C}$ in the absence or presence of inhibitors.

Investigations determined if $300 \mu \mathrm{M}$ leupeptin, $100 \mu \mathrm{M}$ antipain, $3 \mathrm{mM} \mathrm{N}$-ethylmaleimide or benzamidine, or $5 \mathrm{mM}$ iodoacetic acid or iodoacetamide blocked activation of PK on the matrix [4]. Further investigations determined if $\mathrm{PK}$ activation was altered in the presence of ZPP-OH $(1 \mu \mathrm{M}-15 \mathrm{mM})$, antipain $(1 \mu \mathrm{M}-1 \mathrm{mM})$, CTI $(1 \mathrm{nM}-2$ $\mu \mathrm{M})$, FMOC $(0.1 \mu \mathrm{M}-1 \mathrm{mM})$, ATII $(1 \mu \mathrm{M}-1 \mathrm{mM})$, Ang $1-7(1 \mu \mathrm{M}-1$ $\mathrm{mM})$, BK $(10 \mu \mathrm{M}-5 \mathrm{mM})$, or BK $1-5(10 \mu \mathrm{M}-15 \mathrm{mM})$.

\subsection{Plasminogen activation on matrix}

Investigations determined if kallikrein-initiated plasminogen activation was altered by inhibitors of the matrix-associated PK activator $[1,2]$. In these experiments, the matrix was incubated with $100 \mu \mathrm{l}$ of $20 \mathrm{nM} \mathrm{HK}$ in binding buffer containing $50 \mu \mathrm{M} \mathrm{Zn}{ }^{2+}$ for $1 \mathrm{~h}$ at $37^{\circ} \mathrm{C}$. The HK was removed and then the matrix was incubated with $100 \mu \mathrm{l}$ of $20 \mathrm{nM}$ PK in the same buffer for $1 \mathrm{~h}$ at $37^{\circ} \mathrm{C}$ in the absence or presence of FMOC $(300 \mu \mathrm{M})$, aprotinin $(100 \mathrm{nM}), \mathrm{ZPP}-\mathrm{OH}(15 \mathrm{mM})$, Ang 1-7 (1 mM), or ATII (1 mM). The PK was removed by washing and then the matrix was incubated with $100 \mu \mathrm{l}$ of $1 \mu \mathrm{M}$ Glu-plasminogen in binding buffer containing $50 \mu \mathrm{M} \mathrm{Zn}^{2+}$ for an additional $1 \mathrm{~h}$ at $37^{\circ} \mathrm{C}$ in the absence or presence of the same inhibitors. The matrix was then washed to remove the unbound plasminogen. Plasminogen activation was initiated by the addition of ScuPA $(2 \mathrm{nM})$ and $0.3 \mathrm{mM}$ S2251 and hydrolysis of the substrate was measured for $1 \mathrm{~h}$ at $405 \mathrm{~nm}$.

\subsection{Gel electrophoresis and immunoblot}

Microtiter plate cuvette wells covered with HUVEC matrix were incubated with $15 \mu \mathrm{l} /$ well of SDS-PAGE sample buffer for $5 \mathrm{~min}$ at $37^{\circ} \mathrm{C}$. The solubilized contents of three wells were pooled and applied on a $10 \%$ SDS-PAGE. After electrophoresis, the material was electroblotted at $8 \mathrm{~mA}$ overnight onto a nitrocellulose membrane. The membrane then was washed three times with $0.01 \mathrm{M}$ Tris, $0.15 \mathrm{M} \mathrm{NaCl}$, pH 7.4 containing $0.02 \%$ Tween 20 , followed by blocking with $5 \%$ dried milk in the same buffer for $1 \mathrm{~h}$, after which the membrane was incubated with rabbit antiserum against PRCP diluted 1:2000 in Blotto for $1 \mathrm{~h}$ at room temperature $[1,4]$. The membrane was then rinsed three times for $15 \mathrm{~min}$ with buffer followed by incubation with a sheep anti-rabbit $\operatorname{IgG}(1: 500)$ conjugated with horseradish peroxidase for $1 \mathrm{~h}$ at room temperature. After washing again, the membrane was developed with the ECL system and the autoradiograph was prepared.

\section{Results}

Experiments determined if the HUVEC matrix-associated PK activator was inhibited by the same compounds that blocked purified HUVEC PK activator, PRCP [4]. Investigations determined if the matrix-associated PK activator was factor XIIa tightly bound and not exchangeable from the matrix surface. $200 \mu \mathrm{g} / \mathrm{ml} \mathrm{IgG}$ or neutralizing antibody to human factor XIIa did not inhibit PK activation on HUVEC matrix (Fig. 1) [4]. $3 \mathrm{mM}$ benzamidine also had no inhibitory effect on the matrix-associated PK activator. $300 \mu \mathrm{M}$ leupeptin and $100 \mu \mathrm{M}$ antipain inhibited PK activation on HUVEC by 70 and $83 \%$, respectively. Alternatively, cysteine protease inhibitors, $3 \mathrm{mM} N$-ethylmaleimide, $5 \mathrm{mM}$ iodoacetamide, or $5 \mathrm{mM}$ iodoacetic acid, produced little inhibition of PK activation on the matrix. Investigations next determined if the matrix-associated PK activator was blocked by inhibitors previously characterized to inhibit HUVEC PRCP [4]. Increasing concentrations of the prolyl oligopeptidase inhibitors ZPP$\mathrm{OH}$ or FMOC, antipain, or CTI, blocked the matrix-associated $\mathrm{PK}$ activator with an $\mathrm{IC}_{50}$ of $5 \mathrm{mM}, 100 \mu \mathrm{M}, 50 \mu \mathrm{M}$, or $100 \mathrm{nM}$, respectively (Fig. 2).

Further experiments determined that specific substrates of PRCP also inhibited the matrix-associated PK activator (Fig. 3). The peptides ATII or BK, but not Ang 1-7 or BK 1-5, blocked matrix-associated $\mathrm{PK}$ activation with an $\mathrm{IC}_{50}$ of 100 $\mu \mathrm{M}$ or $3 \mathrm{mM}$, respectively (Fig. 3 ).

Studies next determined if the ECV304 cell matrix-associated PK activator was inhibited by the same spectrum of inhibitors as HUVEC matrix-associated PK activator [1]. ATII at $100 \mu \mathrm{M}$, but not Ang 1-7, completely blocked the PK activator from ECV304 cell matrix (Fig. 4). Likewise, CTI and antipain at $1 \mu \mathrm{M}$ and $50 \mu \mathrm{M}$ blocked ECV304 cell

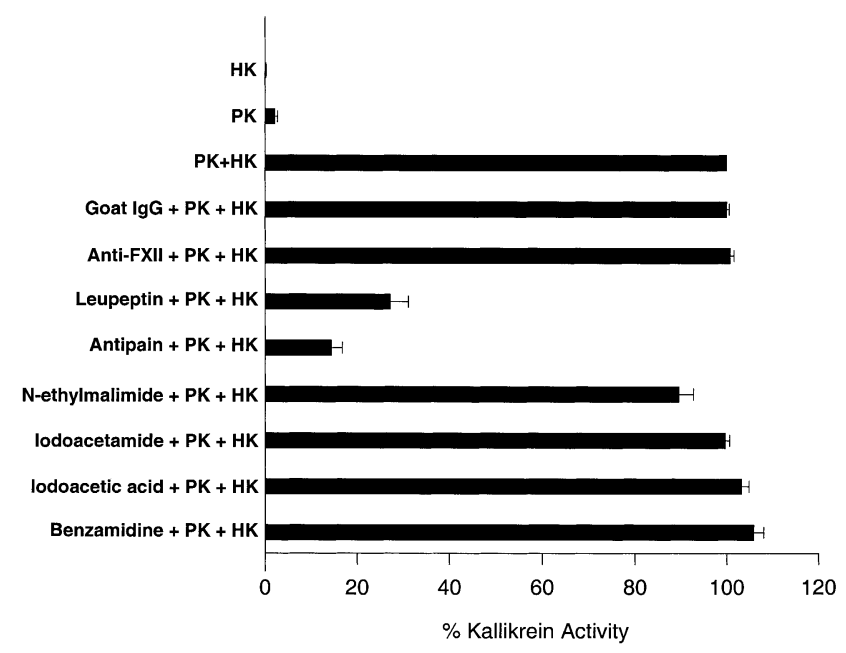

Fig. 1. The nature of the matrix enzyme that activates PK. HUVEC matrix was prepared in 96-well microtiter plates as indicated in Section 2. After washing in binding buffer, the cells were incubated with $20 \mathrm{nM}$ HK for $1 \mathrm{~h}$, after which the wells were washed and incubated with $20 \mathrm{nM}$ PK in the same buffer in the absence or presence of $200 \mu \mathrm{g} / \mathrm{ml}$ goat IgG or goat anti-human factor XIIa antibody, $300 \mu \mathrm{M}$ leupeptin, $100 \mu \mathrm{M}$ antipain, $3 \mathrm{mM} N$-ethylmaleimide, $5 \mathrm{mM}$ iodoacetamide or iodoacetic acid, or $3 \mathrm{mM}$ benzamidine for $1 \mathrm{~h}$ at $37^{\circ} \mathrm{C}$. At the conclusion of the incubation, the wells were washed and the amount of formed kallikrein was measured by hydrolysis of $0.8 \mathrm{mM} \mathrm{S2302}$. The results presented are the mean \pm S.D. of three independent experiments. 


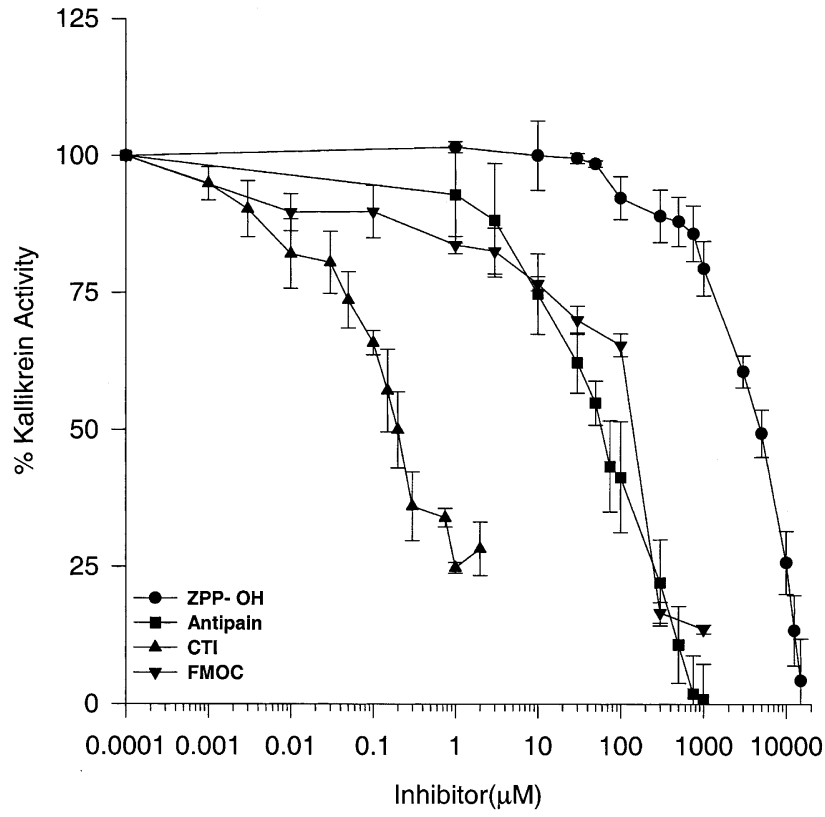

Fig. 2. Specific inhibitors of the matrix-associated PK activating enzyme. HUVEC matrix was prepared and, after incubation with $20 \mathrm{nM} \mathrm{HK}$ as described in Fig. 1, the wells were washed and incubated with $20 \mathrm{nM}$ PK in the absence or presence of $1 \mu \mathrm{M}-15 \mathrm{mM}$ ZPP-OH, $1 \mu \mathrm{M}-1 \mathrm{mM}$ antipain, $1 \mathrm{nM}-2 \mu \mathrm{M}$ CTI, or $0.01 \mu \mathrm{M}-1$ $\mathrm{mM} F M O C$ for $1 \mathrm{~h}$ at $37^{\circ} \mathrm{C}$. At the conclusion of the incubation, the wells were washed and the amount of formed kallikrein was measured by hydrolysis of $0.8 \mathrm{mM} \mathrm{S} 2302$. The results presented are the mean \pm S.D. of three independent experiments.

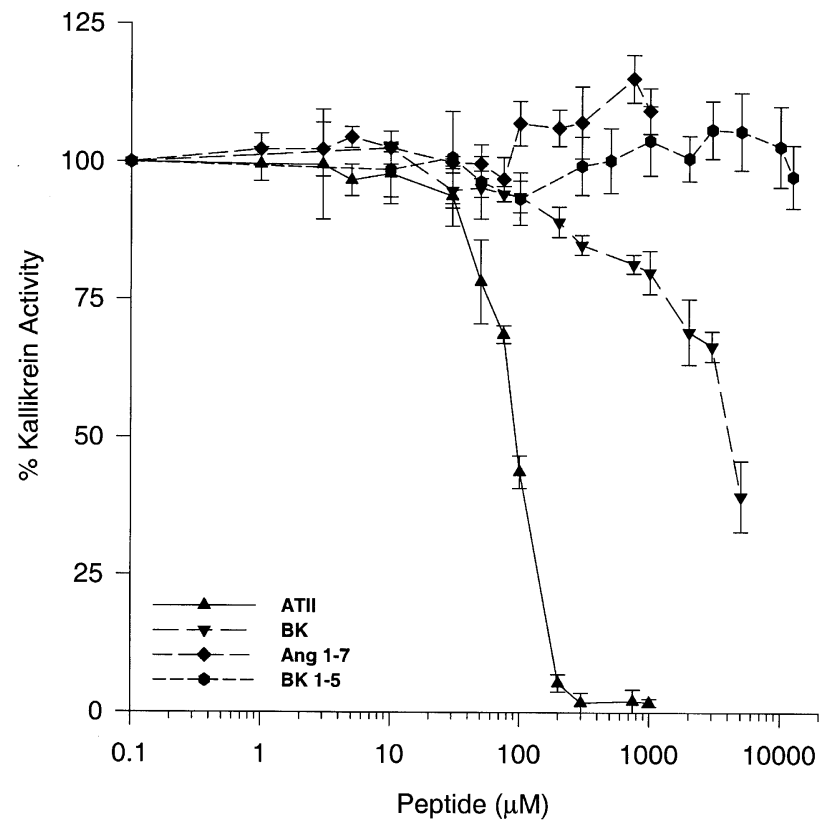

Fig. 3. Substrate inhibitors of the matrix-associated PK activating enzyme. HUVEC matrix was prepared and after incubation with $20 \mathrm{nM} \mathrm{HK}$ as described in Fig. 1, the wells were washed and incubated with $20 \mathrm{nM}$ PK in the same buffer in the absence or presence of $1 \mu \mathrm{M}-1 \mathrm{mM}$ ATII, $10 \mu \mathrm{M}-5 \mathrm{mM}$ BK, $1 \mu \mathrm{M}-1 \mathrm{mM}$ Ang $1-7$, or $10 \mu \mathrm{M}-15 \mathrm{mM}$ BK $1-5$ for $1 \mathrm{~h}$ at $37^{\circ} \mathrm{C}$. At the conclusion of the incubation, the wells were washed and the amount of formed kallikrein was measured by hydrolysis of $0.8 \mathrm{mM} \mathrm{S} 2302$. The results presented are the mean \pm S.D. of three independent experiments.

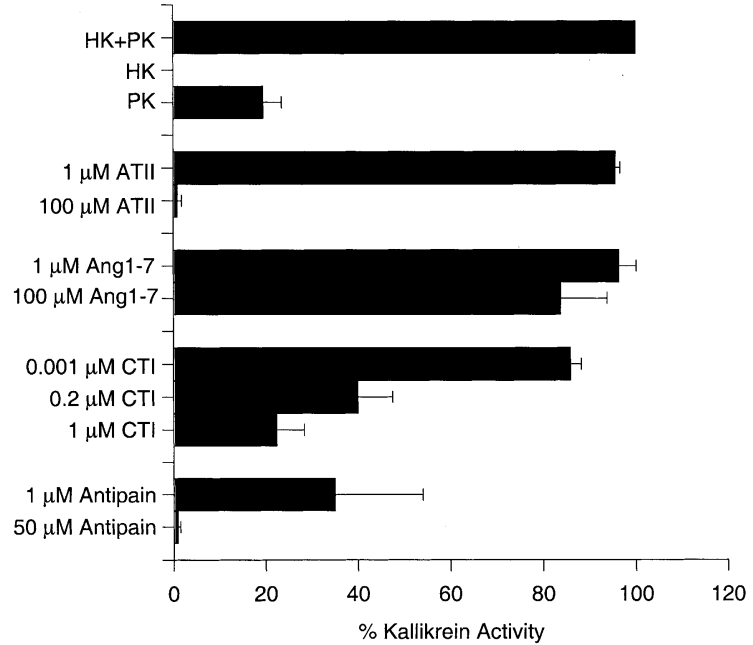

Fig. 4. Inhibition of ECV304 cell matrix-associated PK activating enzyme. ECV304 cell matrix was prepared in 96-well microtiter plates as indicated in Section 2. After washing, the cells were incubated with $20 \mathrm{nM}$ HK for $1 \mathrm{~h}$, after which the wells were washed and incubated with $20 \mathrm{nM}$ PK in the same buffer in the absence or presence of ATII, Ang 1-7, CTI, or antipain at the indicated concentrations for $1 \mathrm{~h}$ at $37^{\circ} \mathrm{C}$. At the conclusion of the incubation, the wells were washed and the amount of formed kallikrein was measured by hydrolysis of $0.4 \mathrm{mM} \mathrm{S} 2302$. The results presented are the mean \pm S.D. of three independent experiments.

matrix-associated PK activator $80 \%$ and $100 \%$, respectively (Fig. 4).

Since kallikrein is a kinetically favorable activator of ScuPA, investigations determined if inhibition of the HUVEC matrix-associated PK activator would block plasminogen ac-

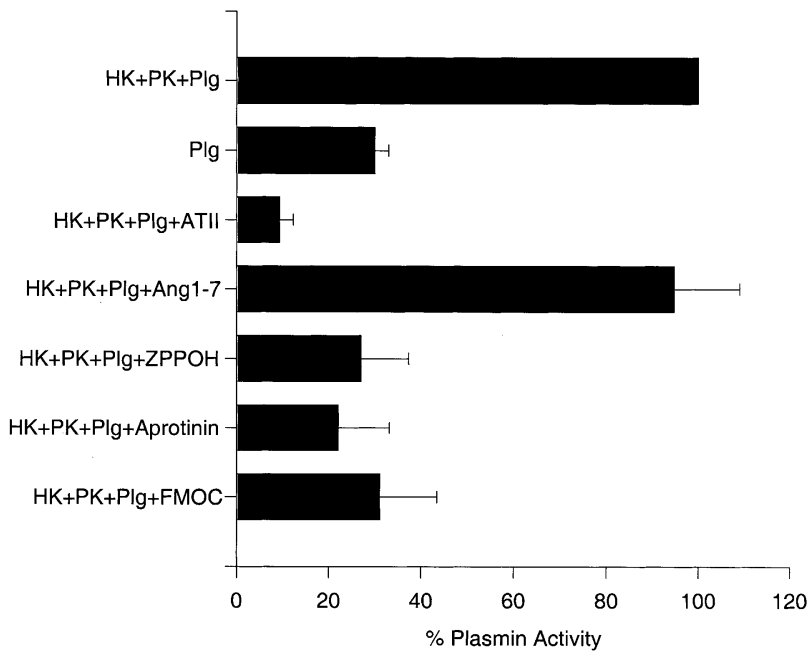

Fig. 5. Inhibition of plasmin formation on HUVEC matrix by inhibition of PK activation. HUVEC matrix was prepared and incubated with $20 \mathrm{nM}$ HK as described in Fig. 1, after which the wells were washed and incubated with $20 \mathrm{nM}$ PK in the same buffer for another $1 \mathrm{~h}$ in the absence or presence of $1 \mathrm{mM}$ ATII, $1 \mathrm{mM}$ Ang 1-7, $15 \mathrm{mM}$ ZPP-OH, $100 \mathrm{nM}$ aprotinin, or $300 \mu \mathrm{M}$ FMOC. At the conclusion of this incubation, the wells were washed and incubated with $1 \mu \mathrm{M}$ Glu-plasminogen in the absence or presence of the same inhibitors for $1 \mathrm{~h}$ at $37^{\circ} \mathrm{C}$. At the conclusion of the incubation, the wells were washed and the amount of formed plasmin was measured by hydrolysis of added $0.3 \mathrm{mM} \mathrm{S} 2251$ in the presence of $2 \mathrm{nM}$ ScuPA. The results presented are the mean \pm S.D. of three independent experiments. 


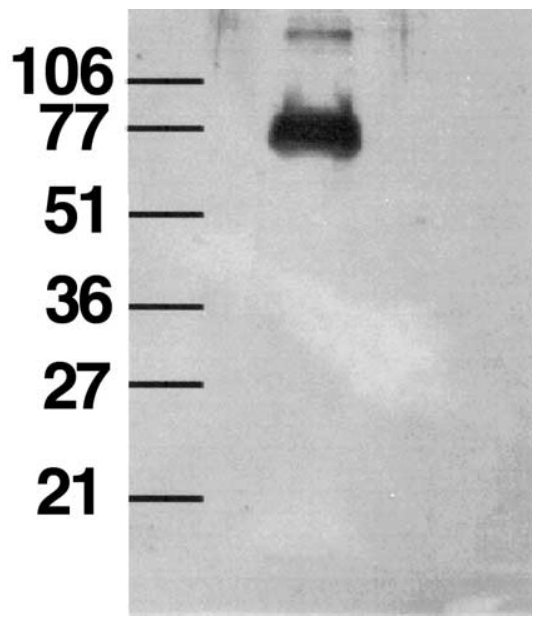

Fig. 6. An immunoblot of matrix-associated PRCP. HUVEC matrix was solubilized by SDS-PAGE sample buffer as indicated in Section 2. The solubilized material was electrophoresed on SDS-PAGE and electroblotted onto nitrocellulose. After blocking the filter, the membrane was incubated with a primary rabbit antibody to human PRCP followed by a secondary anti-rabbit antibody conjugated with horseradish peroxidase. The immunoblot was developed by chemiluminescence.

tivation [1,2,5]. $1 \mathrm{mM}$ ATII, but not Ang 1-7, inhibited 90\% of plasmin formation (Fig. 5). Likewise, $100 \mathrm{nM}$ aprotinin, 15 $\mathrm{mM} \mathrm{ZPP}-\mathrm{OH}$, or $300 \mu \mathrm{M}$ FMOC blocked greater than $70 \%$ of plasminogen activation on HUVEC matrix (Fig. 5).

Lastly, experiments determined if there is immunochemical evidence for matrix-associated PRCP. Solubilized HUVEC matrix on immunoblot expressed human PRCP antigen (Fig. 6).

\section{Discussion}

The combined studies indicate that the HUVEC and ECV304 matrix-associated PK activator is a protease with the same inhibitory features of that described for the PK activator isolated from endothelial cells [4]. The finding that antipain and leupeptin block the activator, but that $N$-ethylmaleimide, iodoacetamide, or iodoacetic acid does not, suggests that it is not cysteine protease. The fact that this activator is inhibited by ATII, FMOC, or ZPP-OH suggests that it is PRCP. ATII with a penultimate proline produces substrate inhibition of PRCP when present in high concentration because it competes with PK for available enzyme. It is also of interest that BK is a weak substrate inhibitor of PRCP. Since BK's proline is in position 7, the carboxy-terminal arginine in position 9 must have been removed first by another carboxypeptidase associated with the matrix. Although to our knowledge no carboxypeptidase has been reported to be associated with endothelial cell matrix, the serine protease deamidase and the metalloproteases carboxypeptidases $\mathrm{M}$ and $\mathrm{N}$ are candidate enzymes to concurrently cleave the C-terminal arginine of $\mathrm{BK}$ to allow for des-Arg ${ }^{9}$-BK to be a substrate inhibitor of PRCP [6]. The presence of PRCP antigen associated with HUVEC confirms that the PK activator is this enzyme. The possibility that the matrices-associated PK activator is not factor XIIa tightly bound and not exchangeable is shown by the fact that neither benzamidine nor a neutralizing antibody to factor XIIa blocked PK activation on the matrix $[1,4]$. CTI blocks the matrix-associated PK activator, but previous studies show that this inhibitor also blocks PRCP in addition to its ability to inhibit factor XIIa [4].

The finding that an enzyme originating in a lysosome is associated with cell matrix is interesting. Recent investigations in cell biology describe the lysosomes of cells as part of the endomembrane compartment that directly communicates with cell membranes to express its constituents [7]. The presence of the PK activator, PRCP, on cell matrix may be important for cellular fibrinolysis. Kinetically favorable activation of single chain urokinase is mediated by plasma kallikrein $[2,8,9]$. Formation of two chain urokinase with subsequent plasmin formation participates in multiple biologic processes such as cell migration and proliferation, tissue remodeling and angiogenesis, and cell growth and wound healing [10,11]. Liberated BK from HK by formed kallikrein also stimulates NO formation and cell proliferation by up-regulating mitogen-activated protein kinase $[2,12,13]$. Lastly, the residual cleaved form of $\mathrm{HK}$, $\mathrm{HKa}$, has the properties to be anti-angiogenic and anti-proliferative, limiting the extent of cell growth and remodeling $[14,15]$. Localization and activation of the proteins of the plasma kallikrein/kinin system on cell matrix indicates new activities of this system in vascular biology.

Acknowledgements: This work was supported by NIH Grant HL52779 to A.H.S., an award from SPDM to G.M., and a grant from CNPq to C.R.M.

\section{References}

[1] Motta, G., Shariat-Madar, Z., Mahdi, F., Sampaio, C.A.M. and Schmaier, A.H. (2001) Thromb. Haemost. 86, 840-847.

[2] Motta, G., Rojkjaer, R., Hasan, A.A.K., Cines, D.B. and Schmaier, A.H. (1998) Blood 91, 516-528.

[3] Rojkjaer, R., Hasan, A.A.K., Motta, G., Schousboe, I. and Schmaier, A.H. (1998) Thromb. Haemost. 80, 74-81.

[4] Shariat-Madar, Z., Mahdi, F. and Schmaier, A.H. (2002) J. Biol. Chem. 277, 17962-17969.

[5] Skidgel, R.A. and Erdös, E.G. (1998) Immunol. Rev. 161, 129141.

[6] Li, J., Wilk, E. and Wilk, S. (1996) J. Neurochem. 66, 21052112.

[7] Biederbick, A., Rose, S. and Elsasser, H.-P. (1999) J. Cell Sci. $112,2473-2484$.

[8] Lenich, C., Pannell, R. and Gurewich, V. (1995) Thromb. Haemost. 74, 698-703.

[9] Lin, Y., Harris, R.B., Yan, W., McCrae, K.R., Zhang, H. and Colman, R.W. (1997) Blood 29, 690-697.

[10] Strand, K., Murray, J., Aziz, S., Ishida, A., Rahman, S., Patel, Y., Cardonna, C., Hammond, W.P., Savidge, G. and Wijelath, E.S. (2000) J. Cell Biochem. 79, 239-248.

[11] Moser, T.L., Enghlid, J.J., Pizzo, S.V. and Satck, M.S. (1993) J. Biol. Chem. 268, 18917-18923.

[12] Zhao, Y., Qiu, Q., Mahdi, F., Shariat-Madar, Z., Rojkjaer, R. and Schmaier, A.H. (2001) Am. J. Physiol. Heart Circ. Physiol. 280, H1821-H1829.

[13] Douillet, C.D., Velarde, V., Christopher, J.T., Mayfield, R.K., Trojanowska, M.E. and Jaffa, A.A. (2000) Am. J. Physiol. Heart Circ. Physiol. 279, H2829-H2837.

[14] Colman, R.W., Jamerson, B.A., Lin, Y., Johnson, D. and Mousa, S.A. (2000) Blood 95, 543-550.

[15] Zhang, J.-C., Claffey, K., Sakthivel, R., Darzynkiewicz, Z., Shaw, D.E., Leal, J., Wang, Y.-C., Lu, F.-M. and McCrae, K.R. (2000) Fed. Am. Soc. Exp. Biol. J. 14, 2589-2600. 